\title{
Correction To: Alligators in the Living Room: Terror and Horror in the Capitalocene
}

\author{
Johan Höglund
}

\section{Correction to:}

Chapter 6 in: S. Blazan (ed.), Haunted Nature, Palgrave Gothic, https://doi.org/10.1007/978-3-030-81869-2_6

The original version of chapter 6 "Alligators in the Living Room: Terror and Horror in the Capitalocene" was previously published non-open access. The chapter has now been changed to open access under the terms of the Creative Commons Attribution 4.0 International License and the copyright holder updated to 'The Author(s)'. The chapter has been updated with these changes.

The updated versions of the chapter can be found at https://doi.org/10.1007/978-3-030-81869-2_6

(C) The Author(s) 2022

S. Blazan (ed.), Haunted Nature, Palgrave Gothic, https://doi.org/10.1007/978-3-030-81869-2_10 